\title{
Induction of a Stable Morphological Change in Propionibacterium freudenreichii
}

\author{
By A. I. NAUD, ${ }^{1}$ J. LEGAULT-DÉMARE ${ }^{1 *}$ AND A. RYTER ${ }^{2}$ \\ ${ }^{1}$ Institut de Microbiologie, Université Paris Sud, Orsay, France \\ ${ }^{2}$ Département de Biologie Moléculaire, Institut Pasteur, Paris, France
}

(Received 7 August 1987)

\begin{abstract}
When cells of Propionibacterium freudenreichii were incubated under fasting conditions and then plated in the presence of an inhibitor of protein synthesis, a variable but significant $\left(>10^{-2}\right)$ fraction of the population changed their morphology from rod to sphere, with a considerable thickening of the cell wall. This change was accompanied by metabolic and antibiotic-resistance modifications, including the synthesis of at least one new enzyme ( $\alpha$-glucosidase), and by the simultaneous appearance of several new species of DNA, presumably plasmids. The round cells grew faster than the parent strain and maintained their morphology indefinitely when propagated on complex medium containing glucose as the main carbon source. However, when glucose was omitted, cells returned to the rod form and regained their previous characteristics, including the absence of detectable plasmids.
\end{abstract}

\section{INTRODUCTION}

Species belonging to the genus Propionibacterium are described in the 8th edition of Bergey's Manual of Determinative Bacteriology as Gram-positive microaerophilic rods, non-motile and asporulate (Moore \& Holdeman, 1974). Their morphology is variable in relation to several factors like the composition of the growth medium or the temperature of incubation. They often appear club shaped and joined in pairs forming a $\mathrm{V}$, a feature characteristic of corynebacteria, but they may adopt branched elongated or coccoid forms. Since their first description (Von Freudenreich \& Orla-Jensen, 1906), the metabolic properties of these bacteria have been the subject of a very large number of publications. Several reviews on the utilization of propionic bacteria in cheese making have also appeared (Hettinga \& Reinbold, 1972). To our knowledge, however, and despite their economic importance, no information is available to date about their genetics.

During the course of our research on the genetic properties of propionibacteria, we occasionally observed on solid media colonies of large round cells, significantly bigger than the 'coccoid' forms. These bacteria were considered to be contaminants until we found they could be obtained in large amounts, under experimental conditions excluding any possibility of contamination or of selection of mutants. The round propionibacteria grew faster than the parent strain and maintained their morphology in complex medium containing glucose as the main carbon source. However, when glucose was replaced with lactate in the same medium, they returned to the rod form.

The procedure used to obtain stable morphological variants in high yields, their ultrastructure and some of their properties are described in this paper.

\section{METHODS}

Bacterial strains. Propionibacterium freudenreichii subsp. shermanii (ATCC 13673) was obtained from the collection of Entremont SA (France). Spontaneous $\mathrm{Lac}^{-}$and chloramphenicol-resistant mutants were isolated from strain ATCC 13673 and designated LM and LM-C, respectively. 
Culture media. A complex medium which allowed fast growth of Propionibacterium was used. The composition of BYC base was as follows: nutrient broth, $5 \mathrm{~g} \mathrm{l}^{-1}$; Casamino acids, $5 \mathrm{~g} \mathrm{l}^{-1}$; yeast extract, $3 \mathrm{~g} \mathrm{l}^{-1} ; \mathrm{NH}_{4} \mathrm{Cl}$, asparagine and glutamine, $0.02 \mathrm{M}$ each; $\mathrm{NaCl}, 0.01 \mathrm{M} ; \mathrm{MgCl}_{2}, 1 \mathrm{mM} ; \mathrm{CaCl}_{2}, 0.1 \mathrm{mM} ; \mathrm{Fe}^{2+}, \mathrm{Co}^{2+}, \mathrm{Mn}^{2+}, \mathrm{Zn}^{2+}$ and $\mathrm{Cu}^{2+}$, $0.01 \mathrm{~mm}$ each. The $\mathrm{pH}$ was adjusted to 6.7. BYCG medium contained BYC base plus $5 \mathrm{~g}$ glucose $\mathrm{l}^{-1}$; $\mathrm{BYCL}$ medium contained BYC base plus $6 \mathrm{~g} \mathrm{~L}(+)$-sodium lactate $\mathrm{l}^{-1}$. Solid BYCG or BYCL media contained $12 \mathrm{~g}$ agar $1^{-1}$. Glucose and lactate were not sterilized separately. MMYC medium was used by Santamaria et al. (1984) for the transformation of Brevibacterium. Probably because of a combination of high $\mathrm{pH}$ and low concentration of yeast extract, this medium does not give measurable growth of Propionibacterium after more than $24 \mathrm{~h}$ incubation. MET medium, containing (in 1 litre of $\mathrm{BYC}$ base) $\mathrm{NaCl}(5 \mathrm{~g})$, sodium acetate $(3 \mathrm{~g})$, L-cysteine $(0.5 \mathrm{~g})$, glucose ( $3 \mathrm{~g})$, sucrose $(2 \mathrm{~g})$ and agar $(15 \mathrm{~g})$, was complemented with $2 \mu \mathrm{g}$ chloramphenicol $\mathrm{ml}^{-1}$ and used in the transformation experiments described here.

In liquid medium, growth was followed at $620 \mathrm{~nm}$. Except when otherwise indicated, cultures in liquid media were incubated in unstirred vials or tubes (static aerobiosis). Anaerobiosis, strictly necessary for growth of isolated colonies on solid media, was achieved using plastic jars or bags with a catalyst obtained from Merck-Clevenot France (Anaerocult).

Fermentation and antibiotic resistance profiles were determined using the API System (API 50CH, ATB Staph, ATB Strep and ATB Ana).

Transformation. P. freudenreichii ATCC 13673 was cultivated on BYCL medium. Cells were harvested at $\mathrm{OD}_{620}$ 0.4 (about $7 \times 10^{8}$ cells ml-1) and resuspended in MMYC at $\mathrm{OD}_{620} 0.03$. At regular intervals (usually 10 or 15 min), between 0 and $4 \mathrm{~h}$ incubation at $30^{\circ} \mathrm{C}$ in static aerobiosis, $1 \mathrm{ml}$ samples of bacterial suspension (about $5 \times$ $10^{7}$ cells) were removed, complemented with $8 \mu \mathrm{g}$ DNA extracted from strain LM-C, and further incubated for $24 \mathrm{~h}$ at $30^{\circ} \mathrm{C}$ under anaerobic conditions. From each sample, $0.1 \mathrm{ml}$ was then plated on solid MET medium containing $2 \mu \mathrm{g}$ chloramphenicol $\mathrm{ml}^{-1}$, and incubated anaerobically for at least $48 \mathrm{~h}$ at $30^{\circ} \mathrm{C}$.

Enzyme activities. Cells were broken by two passages through a French pressure cell at about $173 \mathrm{MPa}$. A sample of the lysate was plated and the number of surviving cells was determined. The yield of broken cells was above $99 \%$ with strain ATCC 13673 and between 50 and $70 \%$ with morphological variants. These values were used in calculating the specific activities of enzymes per cell.

Lysates were centrifuged at $1000 \mathrm{~g}$ for $10 \mathrm{~min}$, and the supernatants were used for enzyme determinations. Lactate dehydrogenases were estimated by following at $620 \mathrm{~nm}$ the rate of reduction of dichlorophenolindophenol (DCIP) at $25^{\circ} \mathrm{C}$, in the presence of either $\mathrm{D}(-)$ - or $\mathrm{L}(+)$-lithium lactate (Snoswell, 1966). One activity unit was defined as $1 \mu \mathrm{mol}$ DCIP reduced $\min ^{-1}$ per $10^{9}$ cells. $\alpha$-Glucosidase was estimated by hydrolysis of $p$-nitrophenyl$\alpha$-D-glucoside (pNPGlu) for $10 \mathrm{~min}$ at $37^{\circ} \mathrm{C}$ in $0.1 \mathrm{M}$-potassium phosphate buffer, pH $7 \cdot 0$, containing $1 \mathrm{mM}-\mathrm{Mg}^{2+}$ and $1 \mathrm{~mm}$-dithiothreitol. After addition of sodium carbonate up to $0.8 \mathrm{M}$, absorbance was read at $400 \mathrm{~nm}$. One activity unit was defined as $1 \mu \mathrm{mol} p \mathrm{NPGlu}$ hydrolysed $\min ^{-1}$ per $10^{9}$ cells.

Detection of plasmids. Cultures $(10 \mathrm{ml})$ in medium BYCG complemented with $2 \%(\mathrm{w} / \mathrm{v})$ glycine were submitted to the 'second procedure' described by Yoshihama et al. (1985). The final DNA precipitate was dissolved in $20 \mu \mathrm{l}$ $40 \mathrm{mM}$-Tris/HCl containing $2 \mathrm{mM}$-EDTA, and subjected to electrophoresis on $0.6 \%(\mathrm{w} / \mathrm{v})$ agarose gels containing $0.5 \mu \mathrm{g}$ ethidium bromide $\mathrm{ml}^{-1}$. DNA bands were observed under UV light.

Electron microscopy. Bacteria grown in liquid medium were spun down and resuspended in fixative comprising $2.5 \%(\mathrm{v} / \mathrm{v})$ glutaraldehyde in $0.1 \mathrm{M}$-sodium cacodylate buffer, $\mathrm{pH} 6.8$, containing $5 \mathrm{mM}-\mathrm{CaCl}_{2}$. After $1 \mathrm{~h}$, the bacteria were washed in the same buffer, concentrated in agar (Whitehouse et al., 1977) and postfixed for $1 \mathrm{~h}$ in $1 \%$ $(\mathrm{w} / \mathrm{v})$ osmium tetroxide dissolved in the same buffer. They were then incubated for $1 \mathrm{~h}$ in $1 \%(\mathrm{w} / \mathrm{v})$ uranyl acetate in $0.1 \mathrm{M}$-veronal buffer, $\mathrm{pH} 6.0$, dehydrated in acetone and embedded in Epon.

\section{RESULTS}

\section{Induction of a morphological change}

An experiment was devised to determine whether $P$. freudenreichii was transformable by homologous DNA after a conventional competence treatment. When following the protocol described in Methods, all the colonies growing on plates with chloramphenicol comprised round cells. The ratio of round to input cells was found to vary largely from one sample to another, without any apparent relationship with the time of sampling. However, it was constantly greater than $10^{-2}$.

The results of one of the above experiments are given in Table 1. Controls provided the following information. (i) Omission of DNA from the competence medium had no effect. Thus, no transformation mechanism is implied in the observed phenomenon. (ii) Preincubation in the competence medium could be replaced by other types of aggression: heat shock $\left(45^{\circ} \mathrm{C}\right)$ in the 


\section{Table 1. Occurrence of round cells after incubation in MMYC medium and plating on} chloramphenicol-containing solid MET medium

The no. of c.f.u. is expressed with respect to $1 \mathrm{ml}$ of incubated suspension, which contained $50 \times 10^{6}$ cells $\mathrm{ml}^{-1}$. All the colonies comprised round cells.

\begin{tabular}{|c|c|c|}
\hline \multirow{2}{*}{$\begin{array}{c}\text { Incubation } \\
\text { time } \\
\text { (min) }\end{array}$} & \multicolumn{2}{|c|}{ c.f.u. } \\
\hline & $10^{-6} \times$ No. of & $\%$ \\
\hline 110 & $1 \cdot 60$ & 4.6 \\
\hline 120 & $1 \cdot 10$ & $3 \cdot 1$ \\
\hline 130 & 0.65 & 1.9 \\
\hline 140 & $4 \cdot 80$ & 13.7 \\
\hline 150 & 0.16 & 0.5 \\
\hline 160 & $2 \cdot 20$ & 6.3 \\
\hline 170 & 1.60 & $4 \cdot 6$ \\
\hline 180 & 0.53 & 1.5 \\
\hline 190 & 0.70 & $2 \cdot 0$ \\
\hline 210 & 6.00 & $17 \cdot 1$ \\
\hline $210^{*}$ & $35 \cdot 0$ & 100 \\
\hline
\end{tabular}

* Control plated on solid medium without chloramphenicol. All the colonies comprised rods. Percentages are expressed with respect to this control.

presence of polyethylene glycol or UV irradiation at a survival rate of about $0 \cdot 1 \%$ (results not shown). (iii) Omission of chloramphenicol from the plating medium allowed treated cells to grow as normal coryneform bacteria. No colonies comprising round cells were observed.

In addition, no morphological change was detectable at any time by phase contrast microscopy of the bacteria incubated in MMYC competence medium. Round cells appeared only after growth on solid medium containing chloramphenicol at a concentration inhibitory for rod cells.

In conclusion, this treatment produced, at a high efficiency, a change in morphology, and, simultaneously, the occurrence of resistance to chloramphenicol. We were unable, however, to make the phenomenon completely reproducible. In some experiments, the yield of round cells relative to input rod cells was more than $50 \%$, but this result, although obtained under apparently identical conditions, was obtained randomly and could not be predicted.

A dozen isolated colonies of round cells, picked at random in different experiments and designated E1, E2 etc., were propagated in BYCG medium at $30^{\circ} \mathrm{C}$. None of them reverted to the rod form when maintained in this medium. They appeared to belong to two different types. (i) Strains growing poorly on $B Y C G$, doubling time about $10 \mathrm{~h}$, maximum $\mathrm{OD}_{620}$ about $0 \cdot 3$. (ii) Strains growing faster than the parent strain, up to an $\mathrm{OD}_{620}$ greater than 1.0 .

One of the strains exhibiting the best growth characteristics, strain E1, was arbitrarily selected to be described here as representative of this new form of $P$. freudenreichii. The generation time of this strain was $4.5 \mathrm{~h}$ under anaerobiosis, and $2 \mathrm{~h}$ under static aerobiosis, in BYCG medium at $30{ }^{\circ} \mathrm{C}$; the generation time for the parent strain was $4.5 \mathrm{~h}$ under both conditions.

\section{Electron microscopy}

Bacteria of strain ATCC 13673, grown in BYCL medium and examined in thin section, had a rod-shaped appearance with a width of $0.5 \mu \mathrm{m}$ (Fig. $1 a$ ). They had a homogeneous cell wall about $20 \mathrm{~nm}$ in thickness. Cell division occurred by the formation of a cross-wall, characteristic of all Gram-positive bacteria.

Bacteria incubated in MMYC medium and plated on solid medium containing chloramphenicol as described in Methods exhibited important morphological modifications. Their shape was spherical, with a diameter of about $1 \mu \mathrm{m}$. During exponential growth, the wall thickness was rather regular and was $40 \mathrm{~nm}$, twice that of rod-shaped bacteria (Fig. 1b,c). In some bacteria, thickened wall portions were found near the septa, which were formed in the equatorial plane of 

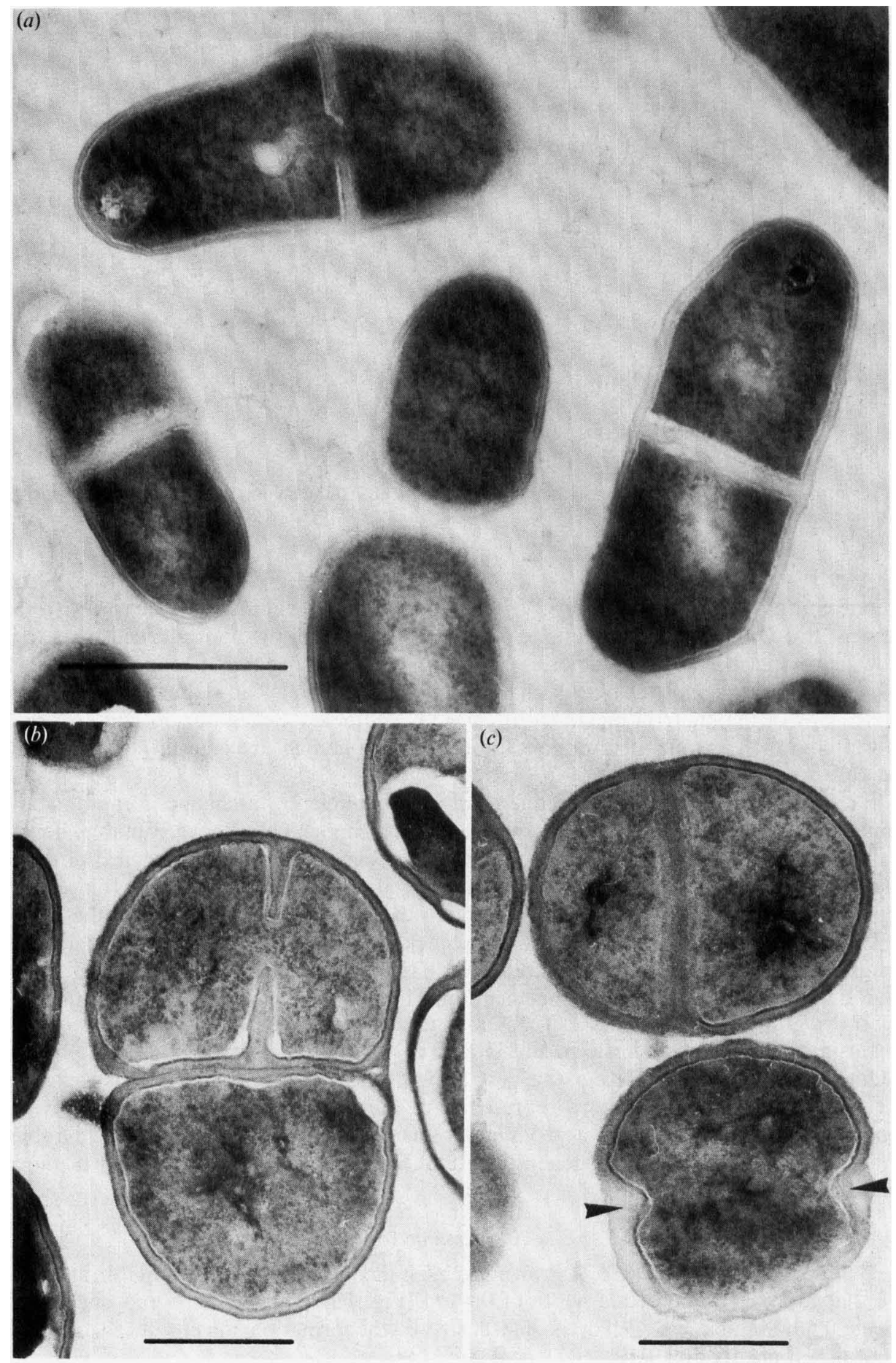

Fig. 1. P. freudenreichii ATCC 13673 growing in BYCG medium. (a) Control cells. ( $b, c)$ Exponentially growing cells after induction of morphological change. These spherical cells have a diameter twice that of rod-shaped bacteria. Their wall is thicker and shows some irregularity in thickness (arrows). Bars, $0 \cdot 5$ $\mu \mathrm{m}$. 

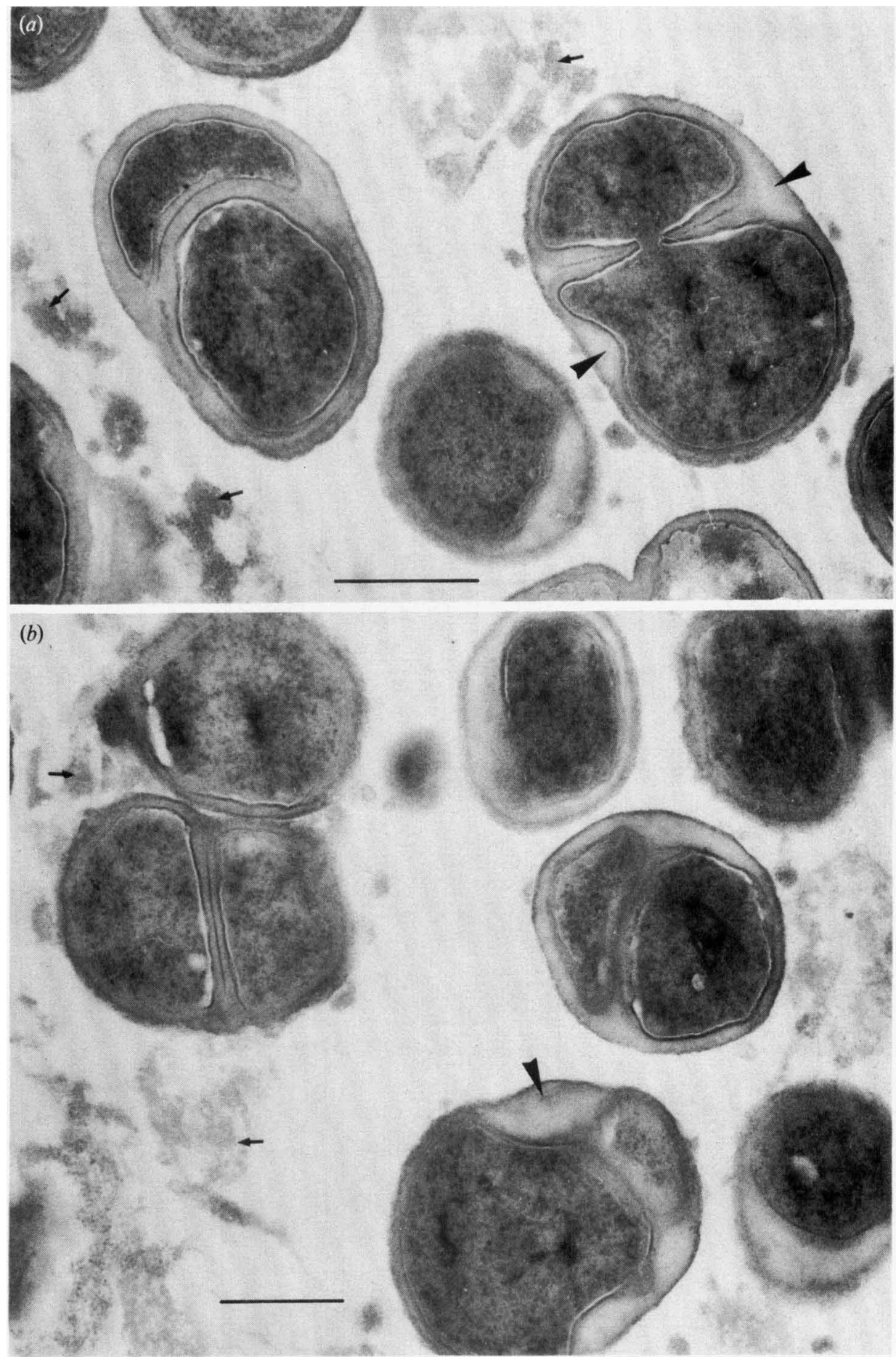

Fig. 2(a,b). Spherical bacteria in stationary phase. The cell wall thickness is very irregular and large dense aggregates seem to detach from the bacterial surface and accumulate in the culture medium (arrows). Bars, $0.5 \mu \mathrm{m}$. 
Table 2. Antibiotic resistance profiles

Concentrations are in $\mu \mathrm{g} \mathrm{ml}^{-1}$. Resistance (growth) or inhibition are indicated by + or - respectively, on the left side for the lowest, and on the right side for the highest concentration.

\begin{tabular}{lcccccc}
\multicolumn{1}{c}{ Low } & High & $\overbrace{13673}^{\text {E1 }}$ & R3 \\
Penicillin & $0 \cdot 25$ & 16 & +- & -- & +- \\
Ampicillin & 4 & 16 & +- & -- & +- \\
Ticarcillin & 16 & 128 & -- & -- & -- \\
Oxacillin & 2 & - & + & - & + \\
Cefoxitin & 4 & 16 & ++ & -- & -- \\
Cefoperazone & 4 & 32 & +- & -- & +- \\
Cefotaxime & 4 & 32 & +- & -- & +- \\
Latamoxef & 4 & 32 & +- & -- & +- \\
Gentamicin & 4 & 8 & ++ & -- & ++ \\
Netilmicin & 4 & 8 & ++ & -- & ++ \\
Dibekacin & 4 & 8 & ++ & -- & ++ \\
Amikacin & 8 & 16 & ++ & -- & ++ \\
Doxycycline & 2 & 8 & -- & -- & -
\end{tabular}

Minocycline

Chloramphenicol

Erythromycin

Josamycin

Pristinamycin

Lincomycin

Clindamycin

Metronidazole

Vancomycin

Fusidic acid

Cotrimoxazole

Foxfomycin

Trimethoprim

\begin{tabular}{|c|c|c|c|c|}
\hline \multicolumn{2}{|c|}{ Conen } & \multicolumn{3}{|c|}{ Strain } \\
\hline Low & High & 13673 & E1 & R3 \\
\hline 4 & 8 & -- & -- & - \\
\hline 2 & 8 & -- & +- & -- \\
\hline 1 & 4 & -- & ++ & - \\
\hline 2 & 8 & -- & +- & - \\
\hline 2 & 4 & -- & -- & -- \\
\hline 2 & 8 & +- & -- & +- \\
\hline 2 & 8 & -- & -- & -- \\
\hline 4 & 32 & $+t$ & ++ & ++ \\
\hline 4 & 32 & -- & -- & - \\
\hline 2 & 16 & -- & -- & -- \\
\hline 2 & 8 & ++ & -- & $+t$ \\
\hline 6 & 32 & ++ & -- & ++ \\
\hline 2 & 8 & ++ & -- & ++ \\
\hline
\end{tabular}




\section{Table 3. Carbohydrate fermentation profiles}

The no. of + is indicative of the estimated intensity of reaction.

$\overbrace{13673 \quad \text { E1 } \quad \text { R3 }}^{\text {Strain }}$

$\overbrace{13673 \quad \text { E1 R3 Rtrain }}^{\text {R3 }}$

\begin{tabular}{|c|c|c|c|}
\hline D-Arabinose & - & - & - \\
\hline L-Arabinose & - & - & - \\
\hline D-Ribose & - & - & - \\
\hline D-Xylose & - & - & - \\
\hline D-Lyxose & - & - & - \\
\hline Galactose & + & + & +++ \\
\hline D-Glucose & $+t+t$ & $++t+$ & $+++t$ \\
\hline D-Fructose & - & $++t+$ & - \\
\hline D-Mannose & $+t+t$ & + & +++ \\
\hline L-Sorbose & - & - & - \\
\hline D-Tagatose & - & - & - \\
\hline Rhamnose & - & - & - \\
\hline D-Fucose & - & - & - \\
\hline L-Fucose & - & - & - \\
\hline Cellobiose & - & - & - \\
\hline Maltose & - & $+t+$ & - \\
\hline Lactose & $+++t$ & +++ & $++t+$ \\
\hline Melibiose & - & - & - \\
\hline Saccharose & - & $t+t+$ & - \\
\hline Trehalose & - & $+t+t$ & - \\
\hline$\beta$-Gentiobiose & - & - & - \\
\hline e & - & - & - \\
\hline$\therefore$ & _ & - & - \\
\hline
\end{tabular}

D-Raffinose
Inulin
Glycerol
Erythritol
Adonitol
Xylitol
D-Arabitol
Dulcitol
Inositol
Mannitol
Sorbitol
Starch
Glycogen
Methyl $\beta$-xyloside
Methyl
$\alpha$-D-mannoside
Methyl
$\alpha$-D-glucoside
Amygdalin
Arbutin
Aesculin
Salicin
$N$-Acetyl-
glucosamine
Gluconate
2-Oxogluconate

$\begin{array}{lll}- & - & - \\ - & - & - \\ + & + & + \\ ++ & - & +t \\ +++ & - & +++ \\ - & - & - \\ - & - & - \\ - & - & - \\ ++++ & - & +++t \\ - & - & - \\ - & - & - \\ - & - & - \\ - & - & - \\ - & - & - \\ - & - & - \\ - & - & - \\ - & - & - \\ - & - & - \\ + & + & + \\ - & - & - \\ - & - & - \\ ++ & - & + \\ - & - & -\end{array}$

the cell. When the separation of the two daughter cells did not occur before the subsequent division, the new septa were generally seen in a plane perpendicular to the first septum.

In stationary phase (Fig. $2 a, b$ ) the bacteria retained their spherical shape but their diameter was less uniform (Fig. $2 a: 0 \cdot 7-1 \cdot 2 \mu \mathrm{m}$ ). In addition, the walls of many bacteria were very thick in some regions and large aggregates of dense material were found in the extracellular medium. These seemed to correspond to large pieces of wall released from the bacterial surface.

\section{Antibiotic resistance profiles}

Antibiotic sensitivities were determined for strains ATCC 13673 and E1. As shown in Table 2 , besides the slight augmentation in chloramphenicol resistance which allowed the isolation of round forms, only one new resistance (to erythromycin) appeared. A weak resistance to josamycin also occurred. The main change in the antibiotic profile was, however, the suppression of resistance to a number of drugs tested ( 15 out of 26). Round cells were sensitive to low concentrations of most aminoglycosides, which may mean that their permeability to these positively charged molecules had been enhanced.

\section{Fermentation profiles}

The most noticeable variations in the physiological activities of the spherical isolates were the loss of the ability to ferment some polyalcohols (erythritol, adonitol and inositol), and the acquisition of the capacity to actively ferment disaccharides containing an $\alpha$-glucosidic linkage (maltose, saccharose and trehalose), and D-fructose (Table 3). Resistance and fermentation profiles of the other round strains isolated were also determined. Only slight differences were observed from one strain to another.

\section{Lactate dehydrogenases}

$P$. freudenreichii ATCC 13673 had a high $\mathrm{D}(-)$-lactate dehydrogenase activity (specific activity 5.6 units, $K_{\mathrm{m}} 12.5 \mathrm{~mm}$ ). L(+)-Lactate dehydrogenase activity was not measurable using 


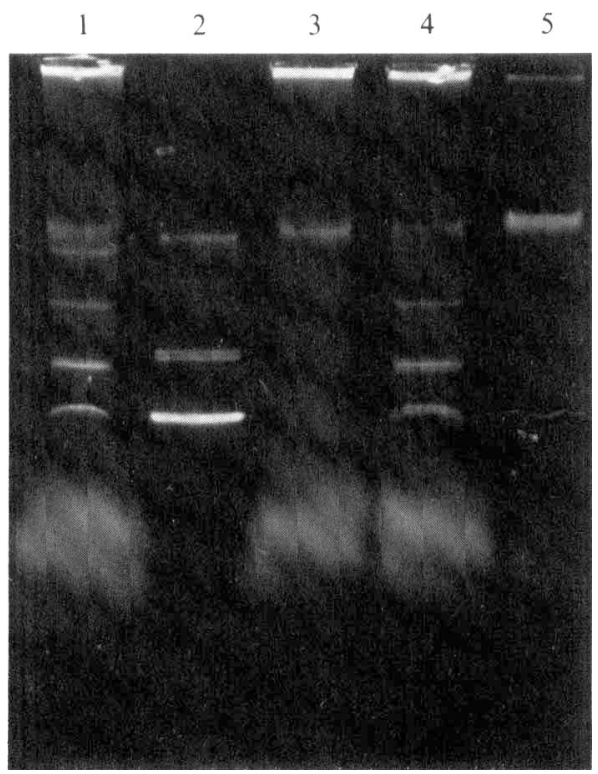

Fig. 3. Agarose gel electrophoresis of DNA extracted by a 'boiling' method. Lane 1, round variant E2; 2, molecular size markers [plasmids pUC8 $(2.7 \mathrm{~kb})$ and pHV33 $(7.3 \mathrm{~kb})$ ]; 3 , rod revertant $\mathrm{R} 1 ; 4$, round variant $\mathrm{E} 1$; 5, parent strain ATCC 13673.

\section{Table 4. Reversion of round cells to the rod form}

Samples of an exponentially growing culture of strain E1 were transferred into BYC base with $(a)$ or without $(b)$ glucose and incubated under static aerobiosis. After the indicated times, samples were withdrawn, diluted according to their optical density to obtain an expected 300 to 500 c.f.u. per plate, and plated on either solid BYCG $(a)$ or solid BYC $(b)$. Colonies were counted after $48 \mathrm{~h}$ incubation at $30^{\circ} \mathrm{C}$. Mean values of five determinations are given.

Time (h)

\begin{tabular}{|c|c|c|c|c|c|c|}
\hline & \\
\hline & \multicolumn{3}{|c|}{ (a) } & \multicolumn{3}{|c|}{ (b) } \\
\hline & 20 & 48 & 115 & 45 & 65 & 115 \\
\hline Expected no. of colonies & 300 & 400 & 460 & 460 & 480 & 460 \\
\hline Round cells & 302 & 392 & 450 & 452 & 387 & 338 \\
\hline Rods & 0 & 0 & 0 & 0 & 77 & 119 \\
\hline Percentage of rods & 0 & 0 & 0 & 0 & 17 & 26 \\
\hline
\end{tabular}

the protocol described in Methods. However, using a test plate assay (I. Caprini, A. Naud \& J. Legault-Démare, unpublished) based on the reduction of nitro blue tetrazolium in the presence of phenazine methosulphate, a slow reaction was observed. Thus, both $\mathrm{D}(-)$ - and $\mathrm{L}(+)-$ activities are present in this strain. A similar result has been obtained by Molinari \& Lara (1960) with $P$. pentosaceum. In strain $\mathrm{E} 1$, only the $\mathrm{L}(+)$ - enzyme was detected by the test plate assay; the reaction rate was of the same order of magnitude as that observed with the parent strain.

\section{$\alpha$-D-Glucosidase}

The ability of strain E1 to ferment $\alpha$-glucosides, revealed by the API test system, correlated with $\alpha$-D-glucosidase activity in cellular extracts. The specific activity of strain E1 was 0.4 units, while it was a hundred times less $(0.004)$ in the parent strain. This latter value is within the range of experimental error and consequently is not significant. 


\section{Detection of plasmids}

Several bands attributable to plasmid DNA were found in extracts of round cells. Most of these extracts contained three bands which seemed to correspond to molecular species common to all the clones tested. [Figure 3 shows the results obtained with two round strains, E1 and E2 (lane 4 and 1, respectively).] In contrast, the parent strain ATCC 13673 did not contain detectable plasmid DNA (Fig. 3, lane 5).

\section{Reversion to the rod form}

Strain E1, as well as the other fast-growing clones obtained during this study, maintained their round form indefinitely when periodically subcultured on BYCG medium from isolated colonies. However, when BYC base, or BYCL medium (containing L-lactate instead of glucose as the main carbon source) were inoculated with strain E1, rod cells progressively appeared. Table 4 shows the results of one of the reversion experiments.

'Revertant' clones were picked up at random, and their resistance and fermentation profiles were determined. As shown in Tables 2 and 3, the revertant clone R3 obtained from strain E1 was identical to the parent strain, except for a slight difference in galactose fermentation, and in the resistance to cefoxitin. Again, minor variations in fermentation profiles were observed between several revertant clones isolated from the same round strain.

Reversion from round to rod shape was accompanied by the disappearance of plasmid DNA bands on agarose gels (Fig. 3, track 3). Thus, the presumptive plasmid DNA was either lost or reintegrated into the bacterial chromosome when the cells regained their previous morphological and physiological characteristics. Experiments using labelled plasmid DNA as a probe are in progress to determine whether it is still present in revertant cells.

One of the revertants obtained from strain El was resubmitted to the procedure described in Methods. Round cells were obtained in yields similar to those observed for the first time with the parent strain ATCC 13673.

\section{DISCUSSION}

The experiments presented here show that $P$. freudenreichii may exist in two stable shapes - as coryneform bacterium or a large thick walled coccus. High efficiency transition from the first state to the other can be triggered by imposing a combination of two different treatments on the bacteria. (i) Preincubation under conditions which do not allow growth of Propionibacterium, or UV irradiation. The result of this stress may be the occurrence of a temporary 'induced' state of a proportion of the population, during which the potential modification would be expressed only if a selective treatment were applied. Such a treatment (ii) was obtained by plating 'induced' cells on solid medium containing chloramphenicol (or erythromycin, results not shown) at a concentration sufficient to inhibit the growth of rods. When stressed cells were either resuspended in BYCG medium or plated on solid medium without antibiotic, they all grew as normal rods and presumably returned to an 'uninduced' state.

This hypothesis does not give a complete explanation of the phenomenon. As stated in Results, the spontaneous appearance of round $P$. freudenreichii is not a rare event. In addition, the fact that a precise yield could not be predicted using our procedure shows that some factors governing the morphological change remain to be investigated.

The role played by chloramphenicol remains to be elucidated. Previous studies of other bacteria demonstrated that synthesis of cell wall material is independent of protein synthesis (Hancock \& Park, 1958), so that amino acid starvation or translation inhibitors both produce a thickening of peptidoglycan layers (Higgins \& Shockman, 1970). However, this is only an apparent analogy between the two situations: in the case of $P$. freudenreichii cell growth was not prevented as colonies were formed, and, once established, the round morphology and the thicker wall were maintained indefinitely in the absence of inhibitor.

The role played by the main carbon source is also difficult to understand. As shown in Results, the 'induced' cells maintain their rod shape when plated on solid BYCG medium without chloramphenicol. Thus, glucose is not able by itself to provoke the appearance of spheres. In 
contrast, even after many generations without chloramphenicol, the omission of glucose is sufficient to induce the reversion of spheres to the rod form. Due to the complex nutritional requirements of Propionibacterium, a more detailed analysis of the implication of carbon sources in the observed phenomenon is not yet possible.

Several spherical mutants of $E$. coli, usually obtained through nitrosoguanidine mutagenesis, have been described. Mutations mapped in genes cya (Kumar, 1976), envB (WestlingHaggstrom \& Normark, 1975) and rodA (Matsuzawa et al., 1973) are pleiotropic; in addition to shape modification, they confer unpredictable enhanced or reduced resistance to a number of mutagenic, antibiotic or surface-active agents. Conditional morphological mutants have been obtained from other Gram-negative bacteria (Satta et al., 1981; Fujiwara \& Fukui, 1972), and from Bacillus spp. (Rogers et al., 1968, 1970, 1971; Boylan \& Mendelson, 1969). In some cases, phenotypic changes in the morphology of mutants have been demonstrated to depend on medium composition (Rogers \& McConnell, 1970; Rogers et al., 1976).

In this respect, $P$. freudenreichii behaves like a 'natural' mutant: in contrast with all the previously published cases, no mutagenesis of any kind was used, and the high yield of shape modification observed with the protocol described here completely excludes the intervention of a mutational mechanism. The changes observed in resistance and fermentation profiles may be tentatively attributed to the obviously important modifications of the structure of the envelope: the loss of the ability to ferment some polyols may be due to the inactivation of a common membrane-linked transport mechanism, viz. the phosphoenolpyruvate phosphotransferase system(s) (Dills et al., 1980). The appearance of a new enzyme may also be explained by an increased permeability to an inducer of the synthesis of the protein. The inducibility of $\alpha$ glucosidase in Propionibacterium has, however, not yet been demonstrated. The synthesis of $\alpha-$ glucosidase might be also prevented by insertion of a plasmid or a prophage into the chromosome of rod cells, at a region of homology located inside the enzyme locus. Thus, expression of the enzyme activity would be possible only after excision of the foreign DNA. Such a mechanism might explain the results reported in Fig. 3: several bands attributable to plasmid DNA were found in extracts of round cells only. Further work is necessary to ascertain the structure of the DNA contained in these bands, but their presence seems to reveal a mechanism of DNA rearrangement accompanying shape modification.

Another case of morphology change perhaps more akin to our observations is offered by the growth cycle of Arthrobacter (Clark, 1972). These bacteria normally evolute from rod to coccus while approaching the stationary phase. The round form of $A$. crystallopoietes can be maintained stably in glucose-salt medium, but reverts to the rod form after addition of some amino acids (Ensign \& Wolf, 1964). The two cases are strikingly similar: no mutagenesis is implied and both Arthrobacter and Propionibacterium in the rod state are typical pleiomorphic coryneforms with a variable Gram stain. We are not aware of differences in fermentation properties, resistance profiles or in the occurrence of plasmids between the two forms of Arthrobacter.

We think that the results presented here may contribute to the study of cell shape control and perhaps add new information to the taxonomy of coryneform bacteria.

This investigation was supported by grants from CNRS (UA 136) and Ministère de l'Education Nationale (Direction de la Recherche). One of us (A. I. N.) received support from Entremont SA. We are indebted to Drs B. Labedan and J. P. Bohin for many helpful discussions.

These studies were done in partial fulfilment of the requirements for a doctoral thesis (A.I.N.).

\section{REFERENCES}

Boylan, R. J. \& Mendelson, N. H. (1969). Initial characterization of a temperature sensitive rod mutant of Bacillus subtilis. Journal of Bacteriology 100, 1316-1321.

ClarK, J. B. (1972). Morphogenesis in the genus Arthrobacter. Critical Reviews in Microbiology 1, 521544.
Dills, S. S., Apperson, A., Schmidt, M. R. \& SAIER, M. H., JR. (1980). Carbohydrate transport in bacteria. Microbiological Reviews 44, 385-418.

Ensign, J. C. \& Wolfe, R. S. (1964). Nutritional control of morphogenesis in Arthrobacter crystallopoietes. Journal of Bacteriology 87, 924-932. 
FuJiwara, T. \& FukUi, S. (1972). Isolation of morphological mutants of Agrobacterium tumefaciens. Journal of Bacteriology 110, 743-746.

Hancock, R. \& PARK, J. T. (1958). Cell-wall synthesis by Staphylococcus aureus in the presence of chloramphenicol. Nature, London 181, 1050-1052.

Hettinga, D. H. \& Reinbold, G. W. (1972). The propionic acid bacteria. A review. Journal of Milk and Food Technology 35, 295-301, 358-372, 436-447.

Higgins, M. L. \& Shockman, G. D. (1970). Early changes in the ultrastructure of Streptococcus faecalis after amino acid starvation. Journal of Bacteriology 103, 244-254.

Kumar, S. (1976). Properties of adenyl cyclase and cyclic adenosine 3',5'-monophosphate receptor protein-deficient mutants of Escherichia coli. Journal of Bactriology 125, 545--555.

Matsuzawa, H., Hayakawa, K., Sato, T. \& Imahori, K. (1973). Characterization and genetic analysis of a mutant of Escherichia coli K12 with rounded morphology. Journal of Bacteriology 115, 436-442.

Molinari, R. \& LARA, F. J. S. (1960). The lactic dehydrogenase of Propionibacterium pentosaceum. Biochemical Journal 75, 57-65.

Moore, W. E. C. \& Holdeman, L. V. (1974). Propionibacterium. In Bergey's Manual of Determinative Bacteriology, 8th edn, pp. 633-641. Edited by R. E. Buchanan \& N. E. Gibbons. Baltimore: Williams \& Wilkins.

ROGERS, H. J. \& MCCONNELL, M. (1970). The role of Lglutamine in the phenotypic change of a rod mutant derived from Bacillus subtilis 168. Journal of General Microbiology 61, 173-141.

Rogers, H. J., MCConnell, M. \& BurdetT, I. D. J. (1968). Cell wall or membrane mutants of Bacillus subtilis and Bacillus licheniformis with grossly deformed morphology. Nature, London 219, 285-288.

Rogers, H. J., MCConnell, M. \& BurdetT, I. D. J. (1970). The isolation and characterization of mutants of Bacillus subtilis and Bacillus licheniformis with disturbed morphology and cell division. Journal of General Microbiology 61, 155-171.
Rogers, H. J., McConnell, M. \& Hughes, R. C. (1971). The chemistry of the cell walls of rod mutants of Bacillus subtilis. Journal of General Microbiology 66, 297-308.

Rogers, H. J., Thurman, P. F. \& Buxton, R. S. (1976). Magnesium and anion requirements of $\operatorname{rod} B$ mutants of Bacillus subtilis. Journal of Bacteriology 125, 556-564.

Santamaria, R., Gil, J. A., Mesas, J. M. \& Martin, J. F. (1984). Characterization of an endogenous plasmid and development of cloning vectors and a transformation system in Brevibacterium lactofermentum. Journal of General Microbiology 130, 2237-2246.

Satta, G., Botta, G., Canepari, P. \& Fontana, R. (1981). Early initiation of deoxyribonucleic acid replication and shortening of generation time associated with inhibition of lateral wall formation by mecillinam. Journal of Bacteriology 148, 10-19.

SNOSWELL, A. M. (1966). DL-Lactate dehydrogenases (NAD-independent) from Lactobacillus arabinosus. Methods in Enzymology 9, 321-327.

Von Freudenreich, E. \& Orla-Jensen, S. (1906). Uber die Emmentalerkase stattindende Propionsaüregarung. Zentralblatt für Bakteriologie, Parasitenkunde, Infektions und Hygiene (Abteilung II) 17, 529.

Westling-Haggstrom, B. \& Normark, S. (1975). Genetic and physiological analysis of an envB spherelike mutant of Escherichia coli $\mathrm{K} 12$ and characterization of its transductants. Journal of Bacteriology 123, 75-82.

Whitehouse, R. S., Benichou, J. C. \& Ryter, A. (1977). Procedure for the longitudinal orientation of rod shaped bacteria and the production of a high cell density of procaryotic and eucaryotic cells in thin section for electron microscopy. Biologie cellulaire 30, $155-158$.

Yoshihama, M., Higashiro, K., Rao, E. A., Akedo, M., Shanabruch, W. G., Follettie, M. T., Walker, G. C. \& Sinskey, A. J. (1985). Cloning vector system for Corynebacterium glutamicum. Journal of Bacteriology 162, 591-597. 